\title{
Pyramids of QTLs enhance host-plant resistance and Bt-mediated resistance to leaf-chewing insects in soybean
}

\author{
María A. Ortega $^{1} \cdot$ John N. All $^{2} \cdot$ H. Roger Boerma ${ }^{1} \cdot$ Wayne A. Parrott $^{1}$
}

Received: 23 October 2015 / Accepted: 11 December 2015 / Published online: 2 January 2016

(C) The Author(s) 2015. This article is published with open access at Springerlink.com

\begin{abstract}
Key message QTL-M and QTL-E enhance soybean resistance to insects. Pyramiding these QTLs with cry1Ac increases protection against Bt-tolerant pests, presenting an opportunity to effectively deploy Bt with host-plant resistance genes.

Abstract Plant resistance to leaf-chewing insects minimizes the need for insecticide applications, reducing crop production costs and pesticide concerns. In soybean [Glycine max (L.) Merr.], resistance to a broad range of leaf-chewing insects is found in PI 229358 and PI 227687. PI 229358's resistance is conferred by three quantitative trait loci (QTLs): M, G, and H. PI 227687's resistance is conferred by QTL-E. The letters indicate the soybean Linkage groups (LGs) on which the QTLs are located. This study aimed to determine if pyramiding PI 229358 and PI 227687 QTLs would enhance soybean resistance to leaf-chewing insects, and if pyramiding these QTLs with Bt (crylAc) enhances resistance against Bttolerant pests. The near-isogenic lines (NILs): Benning ${ }^{\mathrm{ME}}$, Benning $^{\mathrm{MGHE}}$, and Benning ${ }^{\mathrm{ME}+c r y l A c}$ were developed. Benning $^{\mathrm{ME}}$ and Benning ${ }^{\mathrm{MGHE}}$ were evaluated in detached-leaf and greenhouse assays with soybean looper [SBL, Chrysodeixis includens (Walker)], corn earworm [CEW, Helicoverpa zea (Boddie)], fall armyworm [FAW, Spodoptera frugiperda (J.E. Smith)], and velvetbean caterpillar [VBC, Anticarsia
\end{abstract}

Communicated by D. A. Lightfoot.

Wayne A. Parrott

wparrott@uga.edu

1 Institute of Plant Breeding, Genetics and Genomics, University of Georgia, 111 Riverbend Rd., Athens, GA 30602, USA

2 Department of Entomology, University of Georgia, 413 Biological Sciences Building, Athens, GA 30602, USA gemmatalis (Hübner)]; and in field-cage assays with SBL. Benning ${ }^{\mathrm{ME}+c r y l A c}$ was tested in detached-leaf assays against SBL, VBC, and Southern armyworm [SAW, Spodoptera eridania (Cramer)]. In the detached-leaf assay, Benning ${ }^{\mathrm{ME}}$ showed the strongest antibiosis against CEW, FAW, and VBC. In field-cage conditions, Benning ${ }^{\mathrm{ME}}$ and Benning ${ }^{\mathrm{MGHE}}$ suffered $61 \%$ less defoliation than Benning. Benning ${ }^{\mathrm{ME}+c r y l A c}$ was more resistant than Benning ${ }^{\mathrm{ME}}$ and Benning ${ }^{\text {crylAc }}$ against SBL and SAW. Agriculturally relevant levels of resistance in soybean can be achieved with just two loci, QTL-M and QTLE. ME + crylAc could present an opportunity to protect the durability of Bt genes in elite soybean cultivars. These results should assist the development of effective pest management strategies, and sustainable deployment of Bt genes in soybean.

\author{
Abbreviations \\ IPM Integrated pest management \\ SSR Simple sequence repeat \\ SNP Single nucleotide polymorphism \\ Chr Chromosome \\ $\mathrm{cM}$ Centimorgans \\ bp Basepair \\ PI Plant introduction \\ QTL Quantitative trait locus \\ CEW Corn earworm \\ SBL Soybean looper \\ VBC Velvetbean caterpillar \\ FAW Fall armyworm \\ SAW Southern armyworm \\ $\mathrm{Bt}$ Bacillus thuringiensis
}

\section{Introduction}

The production of soybean [Glycine $\max$ (L.) Merr], one of the world's primary sources of vegetable oil and protein 
(Wilcox 2004), is often limited by pests. Worldwide, $11 \%$ of the crop is lost to animal pests, including insects (Oerke 2005). In the USA, the insect pests causing the most impact are: corn earworm [Helicoverpa zea (Boddie)], soybean looper [Chrysodeixis includens (Walker)], velvetbean caterpillar [Anticarsia gemmatalis (Hübner)], bean leaf beetle, [Cerotoma trifurcata (Forster)], green stink bug [Chinavia hilaris (Say)], and southern stink bug [Nezara viridula (L)] (Boethel 2004). The corn earworm (CEW), soybean looper (SBL), velvetbean caterpillar (VBC), and bean leaf beetle are chewing insects capable of defoliating plants entirely. Although soybean plants can withstand moderate levels of leaf damage, high levels of defoliation greatly reduce seed yield and quality (Haile et al. 1998). The efficient use of insecticide applications depends on economic thresholds (ETs), which are based on percent of defoliation and are used to monitor insect populations to prevent them from reaching levels that may cause economic losses. The suggested ETs for leaf-chewing insects in soybean are $35 \%$ defoliation during the vegetative stages and $20 \%$ defoliation during the reproductive stages (Heatherly 2014).

A third of the world's soybean crop was produced in the USA in 2013 (FAOSTAT 2015). The southern states of Alabama, Arkansas, Louisiana, Mississippi, North Carolina, Tennessee, and Virginia harvested just $13.6 \%$ of the US supply; yet farmers in these states spent $\$ 262$ million on insect control to produce a $\$ 5$ billion crop. Despite the control efforts, yield losses to insects amounted to $\$ 234$ million. Thus, the combined costs of insect control and yield loss were equivalent to $\$ 500$ million. CEW, SBL, and stink bugs were the most important species, both in terms of control costs and yield losses (Musser et al. 2014). The need to lower cost of production along with increased concern over insecticide residues in the food chain and environment is incentives to develop insect-resistant cultivars to use in integrated pest management (IPM) strategies. However, these efforts have been hampered by a lack of understanding of the genetic basis of resistance to most insects, in addition to the difficulty of developing insect-resistant cultivars that yield equivalently to the existing cultivars (Lambert and Tyler 1999).

The Japanese soybean landraces 'Kosamame' (PI 171451), 'Miyako White' (PI 227687), and 'Sodendaizu' (PI 229358) are the most widely used sources of resistance to defoliating insects (USDA-ARS 2015). They were initially discovered to be resistant to Mexican bean beetle [Epilachna varivestis (Mulsant)] by Van Duyn et al. (1971, 1972). They also have been reported to be resistant to multiple coleopteran, lepidopteran, and hemipteran insects that are major economic pests of soybean worldwide (Clark et al. 1972; Gary et al. 1985; Hatchett et al. 1976; Hoffmann-Campo et al. 2006; Jones and Sullivan 1979; Komatsu et al. 2004; Lambert and Kilen 1984b; Layton et al. 1987; Li et al. 2008; Luedders and Dickerson 1977; Piubelli et al. 2003; Silva et al. 2013; Talekar and Lee 1988; Talekar and Lin 1994).

Resistance to defoliating insects in PI 171451, PI 227687, and PI 229358 is conferred via both antibiosis and antixenosis (Rector et al. 2000a, b). Antibiosis is a type of resistance in which the plant has a detrimental effect on insect growth, development, and/or reproduction (Painter 1951). Antixenosis or non-preference is a type of resistance in which the plant affects insect behavior, by discouraging oviposition, colonization, or feeding (Kogan and Ortman 1978; Painter 1951). Initial attempts to transfers insect resistance from these plant introductions (PIs) to elite soybean lines were hindered by poor agronomic qualities of the PIs, and by quantitative inheritance of resistance (Boethel 1999). The advent of marker-assisted selection (MAS) has made possible to reduce many of the issues caused by linkage drag (Warrington et al. 2008).

To understand the genetic basis of resistance in these PIs, Rector et al. (1998, 2000a, b) identified a major QTL on Linkage Group (LG) M (now chromosome 7) of PI 171451 and PI 229358. This locus named "QTL-M" accounts for $37 \%$ of antixenosis variance, and up to $28 \%$ of antibiosis variance. In addition, there are two minor QTLs involved in resistance. QTL-H on chromosome (formerly LG H) conditions antixenosis in PI 229358 and PI 171451, and QTL-G on chromosome 18 (formerly LG G) conditions antibiosis in PI 229358. Zhu et al. (2006) demonstrated that QTL-H, and QTL-G only have a detectable effect if QTL-M is present in the genome. These minor QTLs have usually been missed by conventional breeding programs (Narvel et al. 2001).

Hulburt (2002) identified a major insect-resistance QTL in a mapping population from a PI $227687 \times$ 'Cobb' cross. This QTL (QTL-E) on LG E (now chromosome 12) of PI 227687 conveys both antibiosis and antixenosis. QTL-E comaps with the $\mathrm{Pb}$ locus that controls sharp $\left(\mathrm{Pb} b_{-}\right)$vs. blunt $(p b p b)$ leaf pubescence in soybean (Ting 1946). Although there are earlier reports on the effect of pubescence traits on soybean resistance to insect (Hollowell and Johnson 1934; Johnson and Hollowell 1935; Kanno 1996), is the first report that a sharp-trichome locus co-localizes with an insect-resistance QTL. Hulburt et al. (2004) confirmed that sharp-trichome NILs from 'Clark' and 'Harosoy' are more resistant to lepidopterans, compared to the blunt-trichome cultivars. Nevertheless, given that Lambert and Kilen (1984b) showed that PI 227687's resistance is graft-transmissible, it remains possible that resistance is really due to an as of yet unidentified gene linked to $P b$.

Pyramiding is used to combine multiple desirable genes for the same trait into a single genetic background (Ye and Smith 2008). This strategy is advantageous for development of insect-resistant cultivars; it permits genes with 
different modes of action to be combined to obtain more durable resistance. Accordingly, Walker et al. (2002) demonstrated that QTL-M enhances the effectiveness of Bt in soybean plants expressing the crylAc transgene, while Santos et al. (1997) found that the use of cowpea trypsin inhibitor countered the effects of Cry1Ac in arabidopsis. In addition, Zhu et al. (2008) analyzed sixteen NILs carrying all possible combinations of the insect-resistance QTLs from PI 229358 and the crylAc transgene in a 'Benning' background (Boerma et al. 1997). CEW and SBL bioassays confirmed that Cry1Ac is more effective in the presence of insect-resistance QTLs from PI 229358.

The main goal of this research is to enhance soybean resistance to leaf-chewing insects by identifying the best combination of host-plant resistance QTLs. The objectives of this study were to: (1) develop NILs containing novel combinations of the insect-resistance QTLs from PI 229358 and PI 227687; (2) characterize the NILs for their resistance to defoliating insects, and (3) evaluate the effect of the combination of QTL-M, QTL-E, and Bt for controlling Bt-tolerant pests.

\section{Materials and methods}

\section{Characterization of Benning $^{\mathrm{ME}}$ and Benning $^{\mathrm{MGHE}}$}

\section{Development of near-isogenic lines}

The $\mathrm{BC}_{6} \mathrm{~F}_{2}$-derived NILs, Benning ${ }^{\mathrm{ME}}$ and Benning ${ }^{\mathrm{MGHE}}$ [i.e., Benning with QTLs $\mathrm{M}$ and $\mathrm{E}$ in the first case and $\mathrm{M}$, $\mathrm{G}, \mathrm{H}$, and $\mathrm{E}$ in the second case, backcrossed into it] were developed using a marker-assisted backcross approach (Fig. 1). Benning, a Maturity Group VII elite cultivar adapted to Georgia, was used as the recurrent parent. The NIL development took approximately 10 years, and started before SNPs were commonplace. Simple sequence repeat (SSR) markers linked to each QTL were used during backcross and selfing generations to select lines carrying a specific QTL combination. The flanking markers were: Sat_258 (5'-GCGCAATAGATAATCGAAAAACATACAAGA-3' and 5'-GCGGGGAAAGTGAAAACAAGATCAAATA-3') and Satt702 (5'-GCGGGGTTCTGTGGCTTCAAC-3' and 5'-GCGCATTGGAATAACGTCAAA-3') for QTL-M (Zhu et al. 2009); Sct_199 (5'-GCGACAATGGCTATTAGTAACAATCA-3' and 5'-GCGATTTTCTATTTTCCTCACAGTG-3') and Satt191 (5'-CGCGATCATGTCTCTG-3' and 5'-GGGAGTTGGTGTTTTCTTGTG-3') for QTL-G (Zhu et al. 2008); Sat_334 (5'-GCGTAACGTAGCAAATTGACTATAAGA-3' and 5'-GCGTGTGCAAAGACAATTTCAATGA-3') and

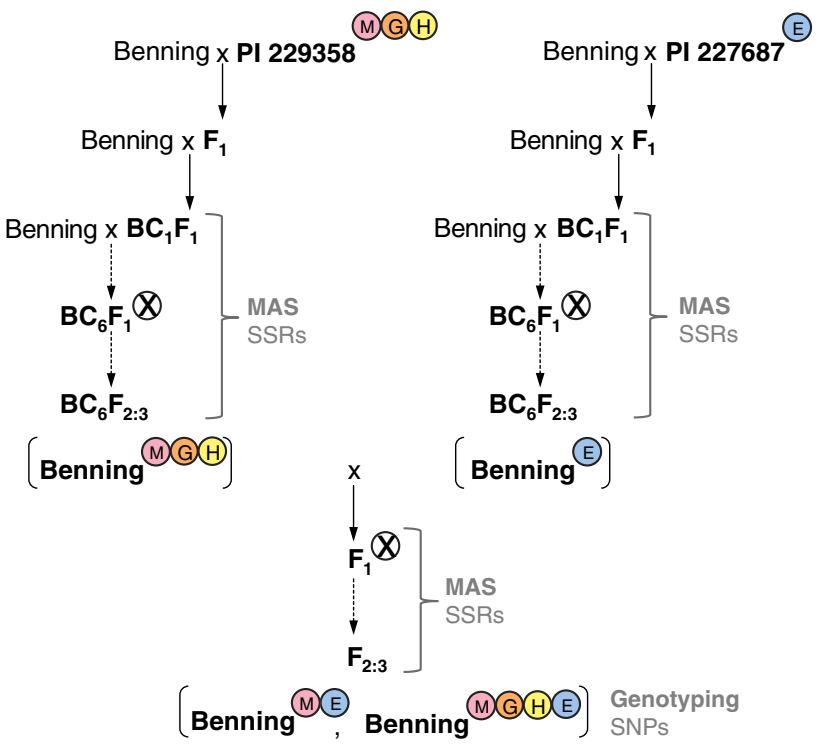

Fig. 1 Breeding scheme for pyramiding insect-resistance QTLs in Benning. Benning ${ }^{\mathrm{MGH}}$ (Zhu et al. 2007) and Benning ${ }^{\mathrm{E}}$, developed from a cross between Benning and PI 227687, were crossed; and the QTL combinations Benning ${ }^{\mathrm{ME}}$ and Benning ${ }^{\mathrm{MGHE}}$ were selected in the progeny. SSRs were used for marker-assisted selection (MAS) of QTL pyramids in each generation, and SNPs (Ortega 2016, personal communications) were used to genotype the plants used in the bioassays

Sat_122 (5'-GTGACAAATGGATGGACAATAG-3' and 5'-AAGAAAAATAAAATAATGTAGAGTGGTGAT-3') for QTL-H (Zhu et al. 2008); and Sat_112 (5'-TGTACAGTATACCGACATAATA-3' and 5'-CTACAAATAACATGAAATATAAGAAATA- $\left.3^{\prime}\right)$ and Satt411 (5'-TGGCCATGTCAAACCATAACAACA-3' ${ }^{\prime}$ and 5'-GCGTTGAAGCCGCCTACAAATATAAT-3') for QTL-E (Hulburt 2002). Primer sequences for the SSR markers were obtained from SoyBase (http://www.soybase. org) (Grant et al. 2010). Genomic DNA isolation, PCR, and electrophoresis protocols for SSRs were performed as described by Zhu et al. (2008). Single nucleotide polymorphism (SNP) markers (Ortega 2016, personal communications) were used to genotype the plants used in the bioassays.

\section{Defoliation}

To estimate defoliation percentage, a soybean leaf defoliation chart (Fig. 2) was built from a collection of chewed leaves for which the percentage of consumed leaf area was calculated in Image J (Rasband 1997). A chart including $5 \%$ increments was the most useful to estimate the percent defoliation in NILs carrying the minor insect-resistance QTLs (QTL-G and QTL-H) in combination with the major QTLs (QTL-M and QTL-E). 

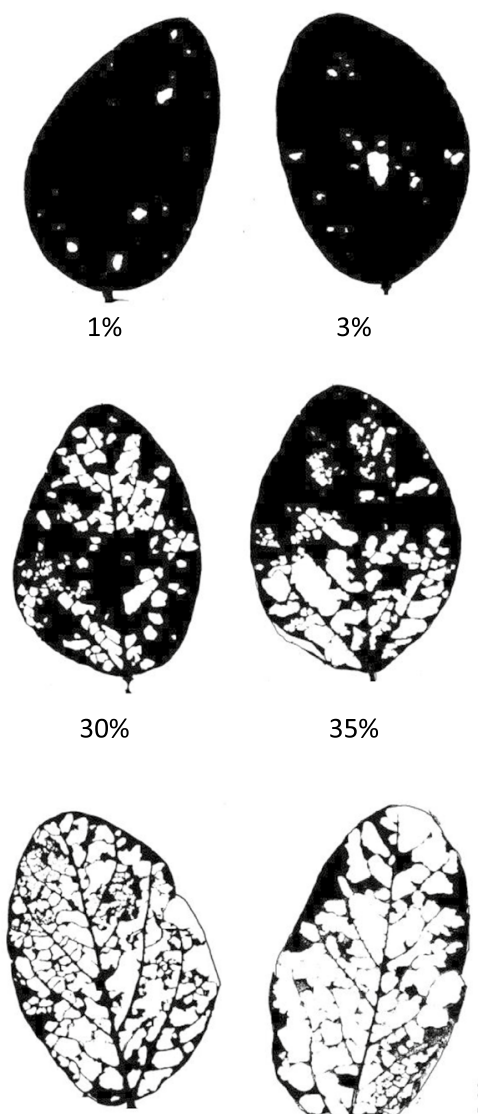

$65 \%$

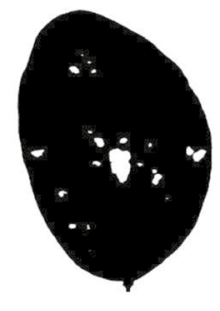

$3 \%$

$35 \%$

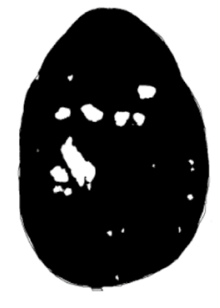

$5 \%$

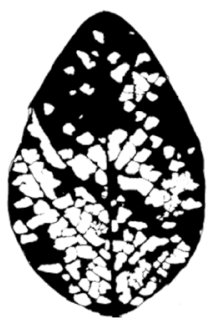

$40 \%$

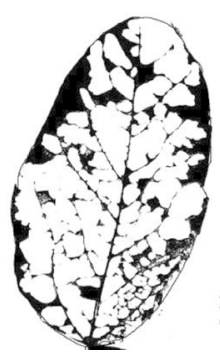

$70 \%$

$75 \%$
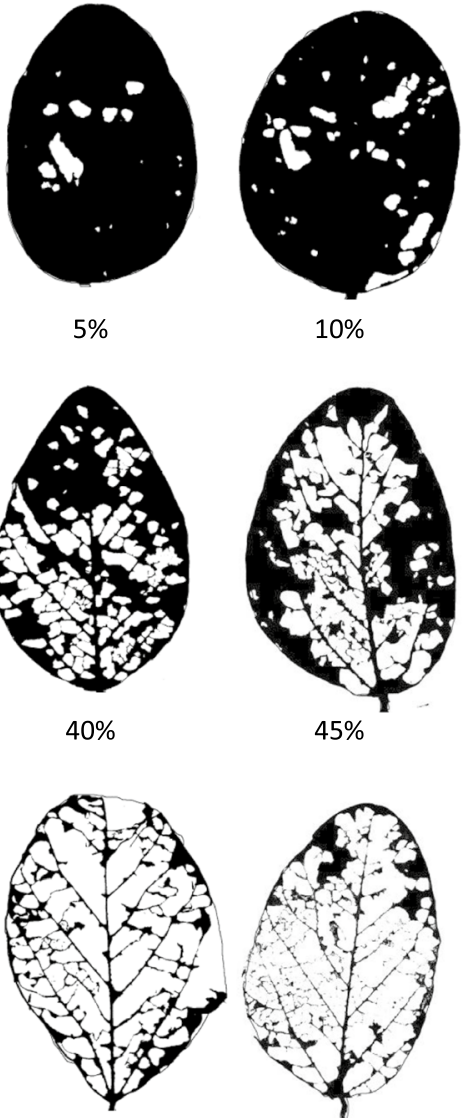

$10 \%$

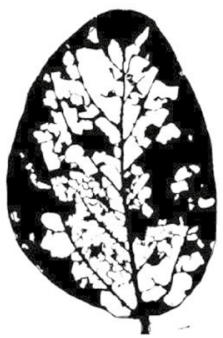

$45 \%$

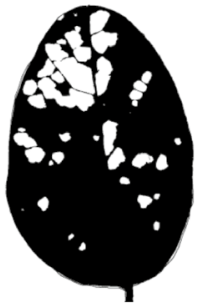

$15 \%$

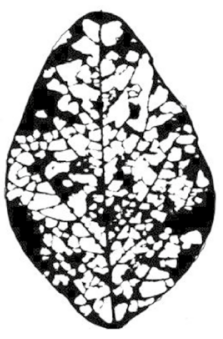

$50 \%$

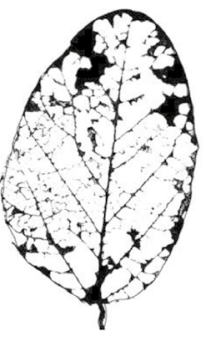

$80 \%$

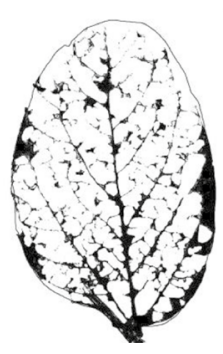

$85 \%$

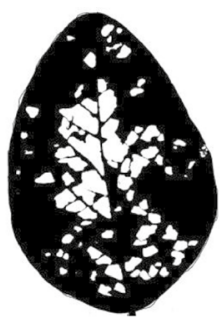

$20 \%$

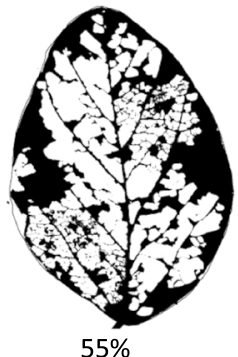

$55 \%$

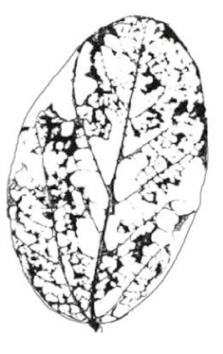

$90 \%$
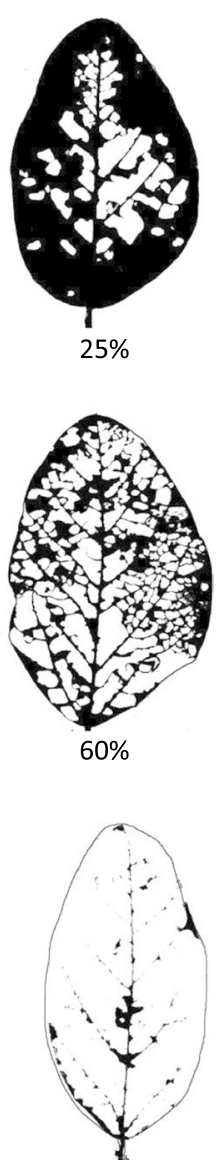

$95 \%$

Fig. 2 Soybean defoliation chart. Percentage of leaf area consumed by herbivores was calculated using Image J

\section{Bioassays}

SBL, CEW, fall armyworm [Spodoptera frugiperda (J.E. Smith)], and VBC caterpillars were used to evaluate the insect-resistant NILs performance in antibiosis, antixenosis, and field-cage assays. Eggs were obtained from Benzon Research Inc. (Carlisle, PA). Eggs were incubated for $72 \mathrm{~h}$ at $25^{\circ} \mathrm{C}$ in a $600-\mathrm{ml}(20 \mathrm{oz})$ clear polystyrene cup (Letica Corporation, Rochester Hills, MI, USA) sealed with a dome lid (Letica Corporation); the cup contained $7 \mathrm{ml}$ of plaster of Paris saturated with water to maintain $75 \%$ relative humidity. Neonate caterpillars were used to infest the bioassays.

Detached-leaf experiments Antibiosis (non-choice) assays were used to determine the effect of the ME and MGHE QTL combinations on caterpillar weight gain. Benning (susceptible check), Benning ${ }^{\mathrm{M}}$, Benning ${ }^{\mathrm{E}}$, Benning ${ }^{\mathrm{H}}$, Benning $^{G}$, and Benning ${ }^{\mathrm{MGH}}$ were included in each experiment. The NILs were tested for antibiosis to SBL, CEW, FAW, and VBC. Each species was evaluated independently using a randomized complete block design with 15 replications. Each replication included one plant from each genotype as the experimental unit. The experimental procedures included: (1) One seed was planted in a 450-ml polystyrene foam cup filled with Fafard 2 mix (Conrad Fafard, Agawam, MA, USA) with three holes punched in the bottom to provide drainage. Plants were grown in an insecticidefree greenhouse under a photoperiod of $16 \mathrm{~h}$. Sunlight was supplemented with $400 \mathrm{~J} \mathrm{~s}^{-1}$ Phillips ED-18 high-pressure sodium lamps (Phillips Inc., Andova, MA, USA) to keep the plants in a vegetative stage. The temperature was regulated to approximately $28{ }^{\circ} \mathrm{C}$ during the day, and $20{ }^{\circ} \mathrm{C}$ at night. Newly expanded trifoliolate leaves were collected, once plants reached the V4 stage (Fehr and Caviness 1977). One trifoliolate leaf was placed into a 600-ml (20-oz) clear polystyrene cup (Letica Corporation) sealed with a dome lid (Letica Corporation). Each cup contained $7 \mathrm{ml}$ of plaster of Paris saturated with water, to maintain $75 \%$ relative humidity. Five SBL or FAW neonate caterpillars were placed in each cup, whereas only one CEW and VBC neonate was used per cup, with two cups per plant, to avoid cannibalism. 


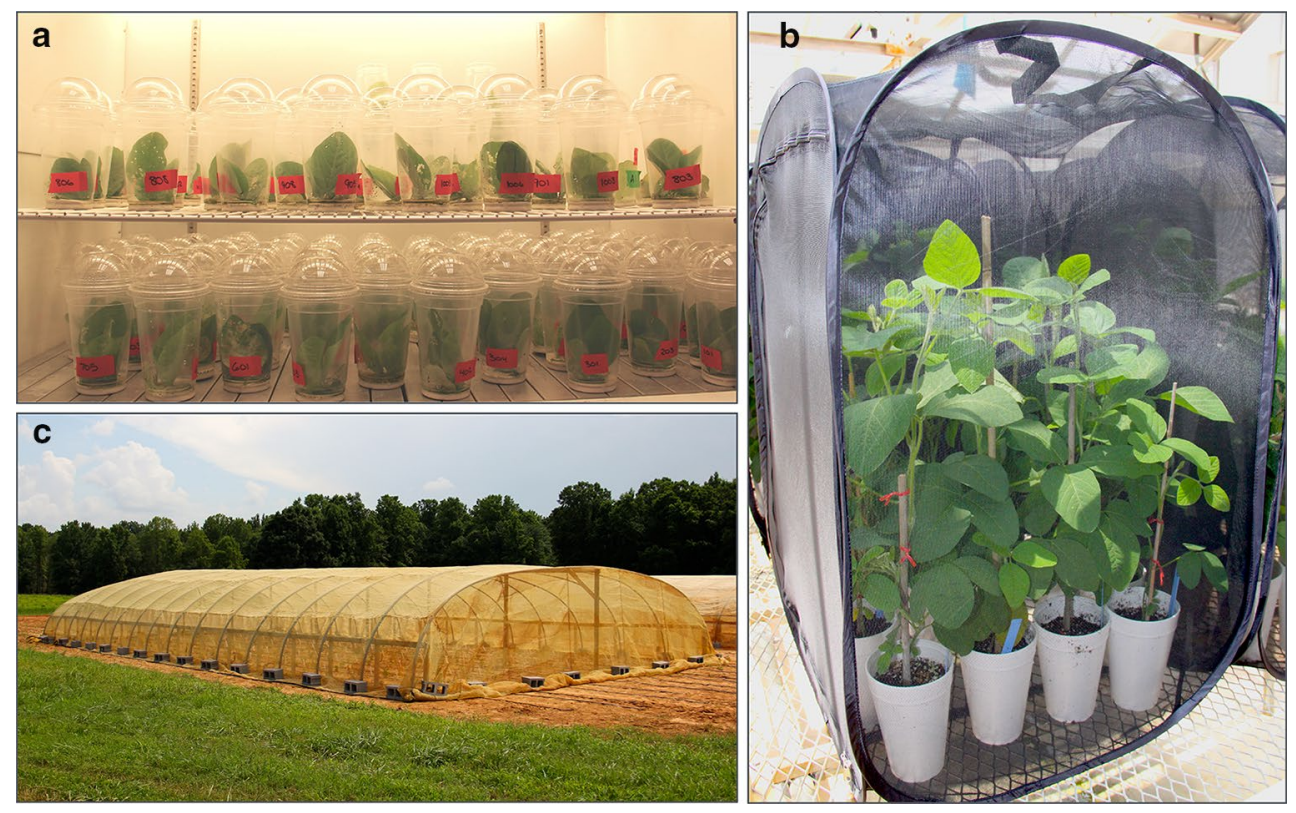

Fig. 3 Insect bioassay settings: a Detached-leaf assay: caterpillars feeding on soybean leaves were contained in plastic cups. b Greenhouse assay: each cage contained caterpillars feeding on a block of test soybeans. c Cage built at the UGA Athens Plant Sciences farm to perform the field-cage assays

lars were able to move from plant to plant at will. Feeding was terminated when defoliation of Benning was higher than $50 \%$, which took approximately 10 days. Percent defoliation of each entire plant was estimated by at least three researchers, and the mean of the estimates for each plant was used for an analysis of variance.

Field-cage experiments This assay was designed to evaluate resistance to SBL under field conditions; resistance was scored as percent defoliation, which includes the effects of antibiosis and antixenosis. A field-cage containing the null, M, E, H, G, ME, MGH, and MGHE NILs was installed at the University of Georgia Plant Sciences Farm (Fig. 3c). The experiment was planted on 1 July 2013 in a randomized complete block design with 15 replications. The experimental unit was a 6-plant hill plot (Bonnett and Bever 1947); each block contained one plot per NIL. Hills were spaced $76.2 \mathrm{~cm}$ apart and were thinned to six plants after germination. A single border row of Benning hill plots surrounded the experiment. After the plants reached the V2 stage, a cage covered with $0.9 \times 0.9 \mathrm{~mm}$ Saran screen (Asahi Kasei, Tokyo, Japan) was placed over the experimental area. This confined the test insects and prevented immigration of parasitoids, predators, and other insect pests. The hill plots were infested when plants reached the V3 stage. Each hill plot was initially infested with 200 caterpillars. After that, 50 neonate caterpillars were added to the each hill plot twice a week for 2 consecutive weeks. The percent defoliation for each hill of plants was estimated by four researchers at 5 , boring plants were in contact with each other, the caterpil- 


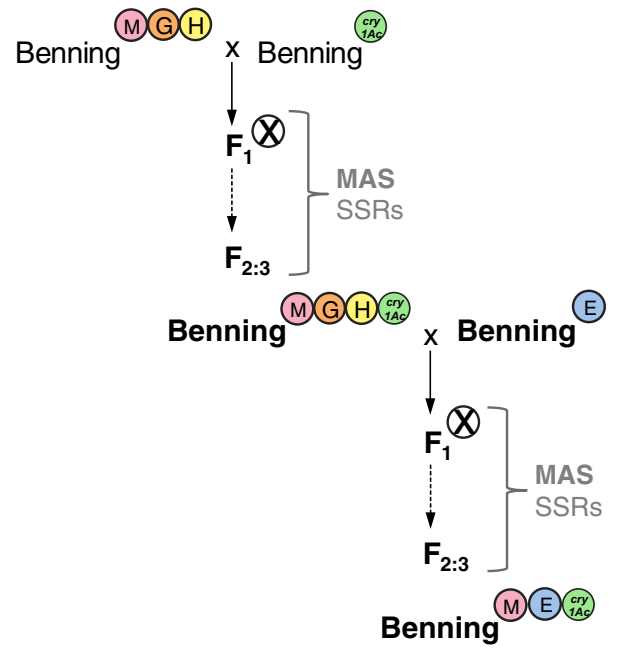

Fig. 4 Breeding scheme for pyramiding insect-resistance QTLs and crylAc in Benning. SSRs were used for marker-assisted selection (MAS) of QTLs in each generation. SNPs (Ortega 2016, personal communications) were used to genotype the plants used in the phenotyping assays

7, 11, and 14 days after the first infestation. A second field cage containing the null, M, E, ME, MGH, and MGHE NILs was planted in 26 August 2013. This cage was infested and evaluated for defoliation as described for the first cage.

\section{Characterization of Benning ${ }^{\mathrm{ME}+c r y 1 A c}$}

\section{Line development}

The Benning ${ }^{\mathrm{ME}+c r y l A c}$ line was developed from a cross between Benning ${ }^{\mathrm{MGH}}$ and Benning ${ }^{c r y l A c}$ (Zhu et al. 2008); the breeding scheme is shown in Fig. 4. The presence of QTL-M and QTL-E was confirmed by genotyping for Sat_258 and Satt702, and for Sat_112 and Satt411, respectively. The presence of crylAc was confirmed by PCR, using the primers described by Stewart et al. (1996).

\section{CrylAc toxin in leaf tissue}

The $c r y l A c$ and $\mathrm{ME}+c r y l A c$ plants were tested for crylAc expression using the Cry1 Ab/Cry1Ac ImmunoStrip test (Agdia Inc., Elkhart, IN, USA). Two leaf punches were collected per plant. Samples were ground in $300 \mu \mathrm{l}$ of SEB4 extraction buffer (Agdia Inc.) using a GenoGrinder 210 (Spex SamplePrep, Metuchen, NJ, USA). Leaf extracts were processed according to the manufacturer's instructions.

\section{Detached-leaf experiments}

SBL, VBC, and southern armyworm (SAW) [Spodoptera eridania (Cramer)] were used in non-choice assays to determine the effect of the ME+crylAc pyramid on caterpillar weight gain. These species were chosen because they vary in their sensitivity to Cry1Ac; SBL and VBC are susceptible, while SAW is resistant (Bernardi et al. 2014b). Eggs were obtained from Benzon Research Inc. (Carlisle, PA, USA). In each assay, Benning, Benning ${ }^{\mathrm{ME}}$, and Benning ${ }^{\text {crylAc }}$ were included as controls. The assays were set up and evaluated, as described in the previous section. Each assay consisted of a randomized complete block design with six replications. For the SAW assay, one cup containing five caterpillars was used to test each plant.

\section{Data analyses}

Data recorded from antibiosis, antixenosis, and field-cage assays were analyzed using JMP statistical software version 10.0 (SAS Institute, Inc., Cary, NC, USA). Each dataset was tested for normality using the Shapiro-Wilk test $(P>0.05)$ (Shaphiro and Wilk 1965). A one-way ANOVA test $(P>0.01)$ was used to detect any difference among genotypes and experimental blocks, and a post hoc TukeyKramer multiple comparison test $(P>0.01)$ (Kramer 1956, 1957; Tukey 1953) was used to determine significant differences between genotypes.

\section{Results}

\section{Characterization of Benning ${ }^{\mathrm{ME}}$ and Benning ${ }^{\mathrm{MGHE}}$}

\section{Detached-leaf experiments}

The results for the non-choice assays are shown in Fig. 5. MGHE had the strongest antibiotic effect against SBL; SBL feeding on Benning ${ }^{\mathrm{MGHE}}$ was $48 \%$ smaller than that feeding on Benning. However, ME had the strongest antibiotic effect against CEW, FAW, and VBC. CEW feeding on Benning ${ }^{\mathrm{ME}}$ weighed $83 \%$ less than CEW feeding on Benning. FAW feeding on Benning ${ }^{\mathrm{ME}}$ weighed $69 \%$ less than that feeding on Benning. Finally, VBC feeding on Benning $^{\mathrm{ME}}$ weighed $70 \%$ less than VBC feeding on Benning. Lines carrying QTL-H and QTL-G did not show antibiosis to any of the insect species.

\section{Greenhouse experiments}

Results for the SBL, CEW, FAW, and VBC choice assays are shown in Fig. 6. The pyramided NILs Benning ${ }^{\mathrm{ME}}$, Benning $^{\mathrm{MGH}}$, and Benning ${ }^{\mathrm{MGHE}}$ were the least defoliated across the four experiments. In the SBL and CEW bioassays, the combinations ME and MGHE were as resistant as MGH $(P>0.01)$. Benning ${ }^{\mathrm{ME}}$ tended to have less SBL defoliation than Benning ${ }^{\mathrm{MGH}}$ and Benning ${ }^{\mathrm{MGHE}}$; however, this difference was not significant. Similarly, Benning ${ }^{\mathrm{MGHE}}$ tended to 


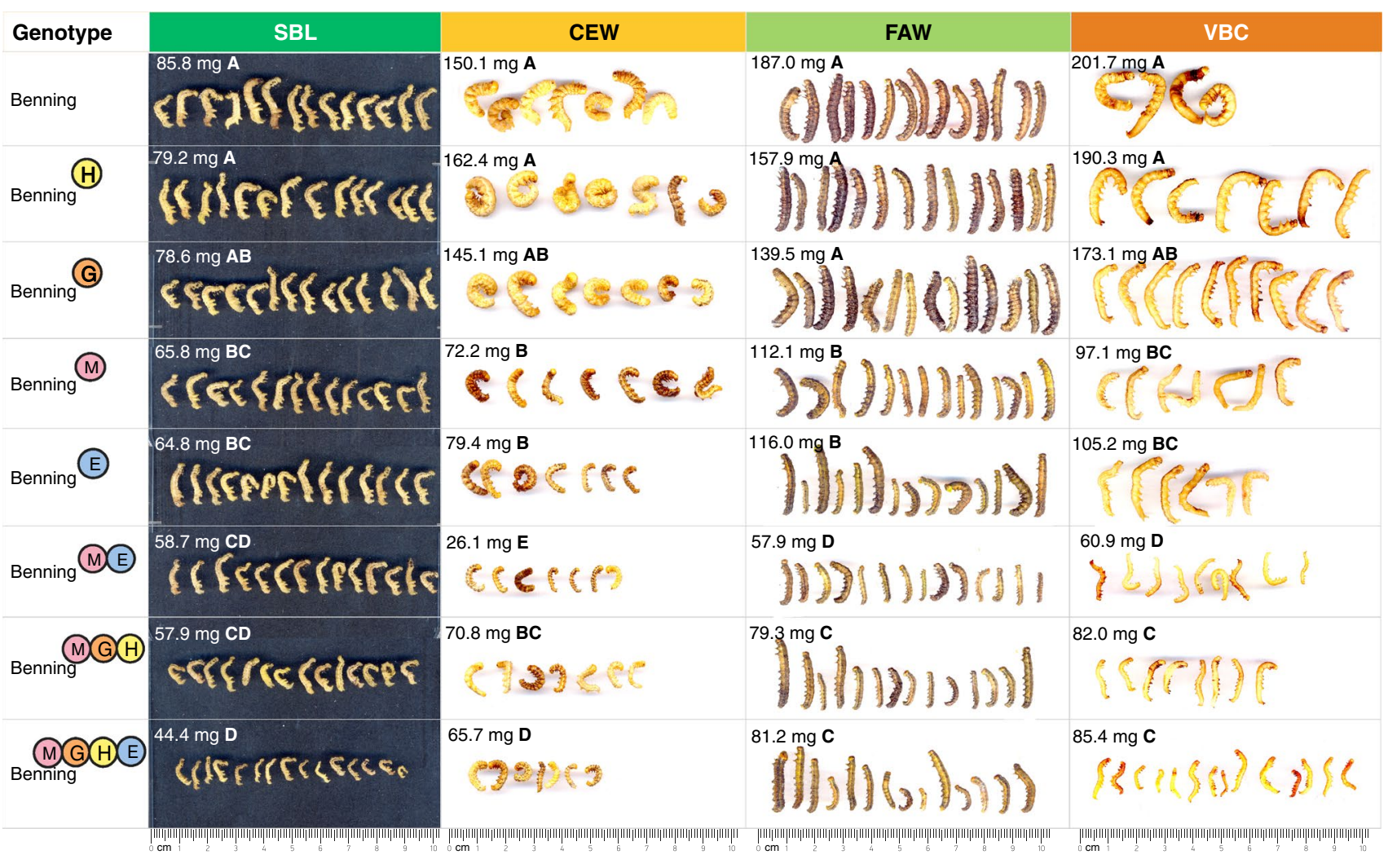

Fig. 5 Mean weight of SBL, CEW, FAW, and VBC caterpillars after feeding on insect-resistant NILs during detached-leaf (antibiosis) assays. Significant differences (Tukey-Kramer post hoc test, $p<0.05$ ) between NILs are indicated by letters

have less CEW defoliation than Benning ${ }^{\mathrm{ME}}$ and Benning$\mathrm{MGH}^{\mathrm{M}}(13.3 \%)$. In the FAW and VBC bioassays, Benning ${ }^{\mathrm{ME}}$ was more resistant than Benning ${ }^{\mathrm{MGH}}$, but not significantly different from Benning ${ }^{\mathrm{MGHE}}(P>0.01)$.

Benning and Benning ${ }^{\mathrm{G}}$ were the most susceptible lines averaged across experiments. Benning ${ }^{\mathrm{H}}$ showed resistance to CEW and VBC assays; however, QTL-H alone failed to protect the plants from SBL and FAW caterpillars. Benning $^{\mathrm{M}}$ and Benning ${ }^{\mathrm{E}}$ were the most resistant single-QTL NILs. QTL-M and QTL-E provided similar levels of resistance against SBL, VBC, and FAW. Nonetheless, Benning $^{\mathrm{M}}$ was significantly more resistant against $\mathrm{VBC}$ than Benning ${ }^{\mathrm{E}}$.

\section{Field-cage experiments}

Defoliation progression in cage 1 . The mean percentage of defoliation on each NIL at 5, 7, 11, and 14 days after infestation is shown in Fig. 7. At 5 days, defoliation ranged between 12 and $18 \%$, and no significant differences were observed between the NILs. At 7 days, Benning showed the most defoliation (32\%) and Benning ${ }^{\mathrm{ME}}$ was the least defoliated $(14 \%)$. At this time point, caterpillars were actively moving between hills, and towards the Benning hills used as borders. At 11 days, susceptible and resistant hills were easily distinguishable (Fig. 8); Benning still showed the most defoliation $(63 \%)$ and Benning ${ }^{\mathrm{ME}}$ was the least defoliated $(26 \%)$. At day 14 , the rate of feeding was significantly slower; few caterpillars had migrated to the resistant NILs, but the majority of them were located on the cage's mesh.

Defoliation in cage 1 . The data collected at 11 days after infestation were analyzed to determine differences in levels of resistance among NILs. This time point was selected, because the plants were highly defoliated and the caterpillars were still highly active. Benning ${ }^{\mathrm{ME}}(21 \%)$, BenningMGH $(25 \%)$, and Benning ${ }^{\mathrm{MGHE}}(27 \%)$ were the most resistant lines in this cage, followed by Benning ${ }^{\mathrm{E}}(52 \%)$ and Benning $^{\mathrm{M}}(38 \%)$, which were moderately resistant. Benning $(63 \%)$ Benning ${ }^{\mathrm{H}}(62 \%)$, and Benning ${ }^{\mathrm{G}}(61 \%)$ were the most susceptible (Fig. 9a).

Defoliation in cage 2. Benning ${ }^{\mathrm{G}}$ and Benning ${ }^{\mathrm{H}}$ were excluded, because in the first cage they were not resistant to SBL. Benning ${ }^{\mathrm{MGHE}}$ (27\%) was the most resistant line in this cage, followed by Benning ${ }^{\mathrm{ME}}(34 \%)$ and Benning ${ }^{\mathrm{MGH}}$ $(39 \%)$. Benning ${ }^{\mathrm{E}}(65 \%)$ and Benning ${ }^{\mathrm{M}}(45 \%)$ were more defoliated than Benning ${ }^{\mathrm{ME}}$ and Benning ${ }^{\mathrm{MGH}}$ in this cage; however, Benning ${ }^{\mathrm{E}}$ and Benning ${ }^{\mathrm{M}}$ were less defoliated than Benning (75\%) (Fig. 9b). 
Fig. 6 Mean defoliation by SBL, CEW, FAW, and VBC caterpillars on NILs during greenhouse (antixenosis) assays. Significant differences (TukeyKramer post hoc test, $p<0.05$ ) between NILs are indicated by letters
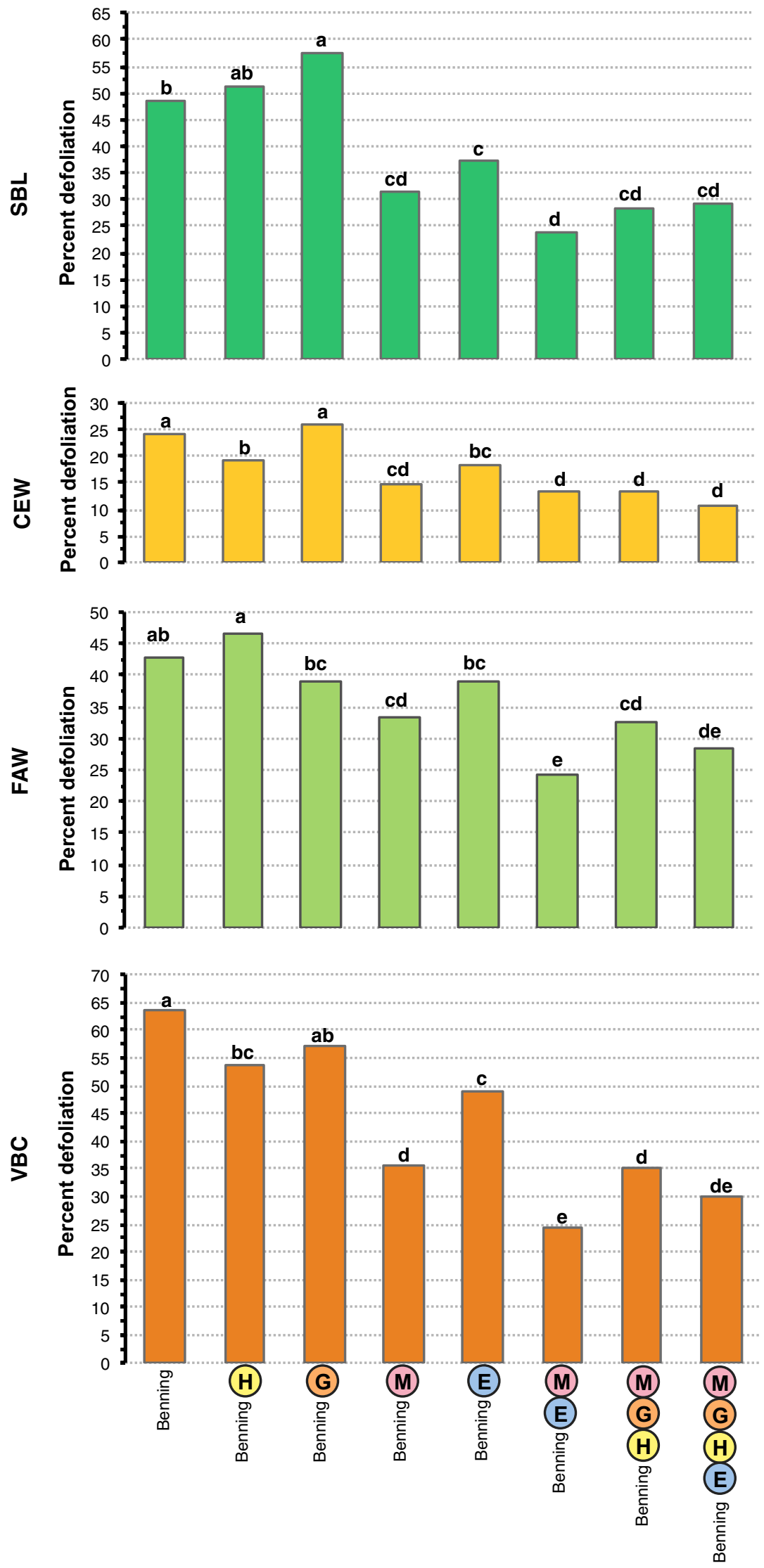
Fig. 7 Feeding progression of SBL in the first field cage. Percentage of defoliation per hill was recorded at 5, 9, 11, and 14 days after the first infestation. Each time point shows the mean defoliation per NIL

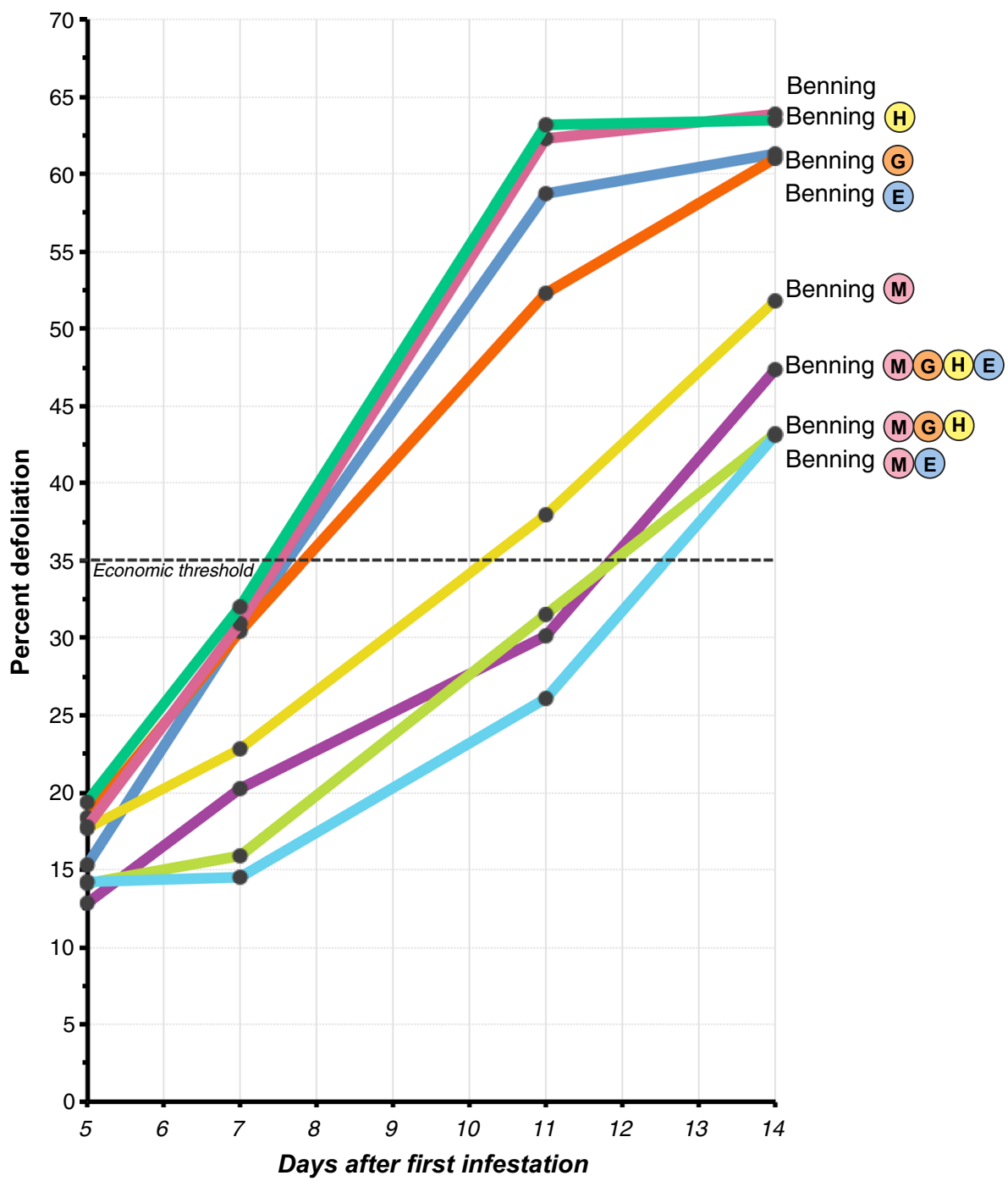

\section{Characterization of Benning ${ }^{\mathrm{ME}+\mathrm{cry} I A c}$}

\section{Detached-leaf experiments}

The results for the non-choice assays are shown in Fig. 10. The pyramid of QTL-M, QTL-E, and crylAc showed enhanced antibiosis against SBL and SAW when compared to Benning ${ }^{\mathrm{ME}}$ and Benning ${ }^{\text {crylAc }}$. SBL fed on Benning $^{\mathrm{ME}}$ and Benning ${ }^{\text {crylAc }}$ weighed $61 \%$ and $43 \%$ less than SBL fed on Benning. However, the strongest antibiotic effect against SBL was observed in Benning ${ }^{\mathrm{ME}+\text { crylAc} \text {; }}$ these caterpillars weighed $88 \%$ less than Benning-fed caterpillars. SAW fed on Benning ${ }^{\mathrm{ME}}$ and Benning ${ }^{\text {crylAc }}$ weighed $68 \%$ and $59 \%$ less than SAW fed on Benning. The strongest antibiotic effect against SAW was observed on Benning ${ }^{\mathrm{ME}+c^{2} y l A c}$; these caterpillars weighed $89 \%$ less than those fed on Benning. VBC fed on Benning ${ }^{\mathrm{ME}}$ weighed $81 \%$ less than VBC fed on Benning. VBC fed on Benning ${ }^{\text {crylAc }}$ died at the first instar; their weight was $98 \%$ less than Benning-fed VBC. VBC fed on Benning ${ }^{\mathrm{ME}+c r y l A c}$ also died at the first instar; therefore, the effect of QTL-M and QTL-E could not be measured for this species.

\section{Discussion}

PI 229358 and PI 227687 have been used in soybean breeding programs worldwide to introgress resistance to chewing insects. This is the first time that the resistance of NILs carrying pyramids of insect-resistance QTLs from PI 229358 and PI 227687 has been evaluated. The rationale was based on work by Lambert and Kilen (1984a), showing that $\mathrm{F}_{1}$ progeny from PI 229358 X PI 227687 are more resistant than either parent. In this study, it was demonstrated that the QTL combinations ME and MGHE are able to confer high levels of resistance against multiple insect species via antibiosis and antixenosis, in the cultivar, Benning. The ME and MGHE 

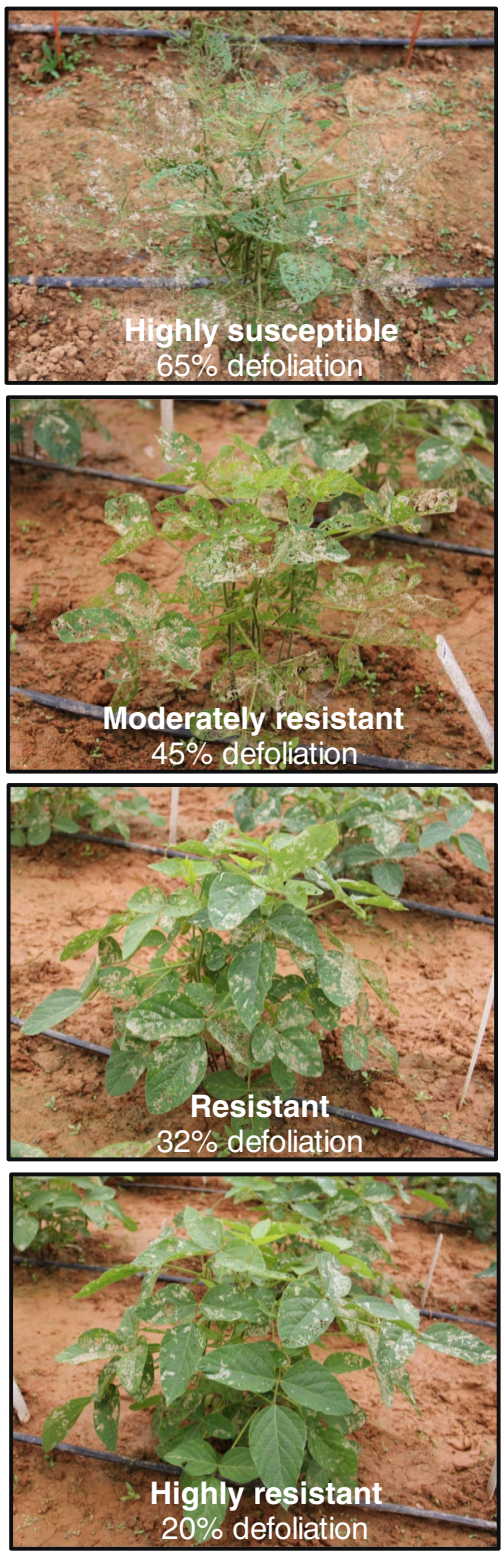

Fig. 8 Leaf damage on NILs exposed to SBL feeding in the field cage, at 11 days after infestation

NILs exhibit similar levels of resistance in all but one of the bioassays. Therefore, there is no indication that the addition of QTL-G and/or QTL-H to the ME combination is required to reach agriculturally relevant levels of resistance. Although the results of are encouraging, a limitation of this study might be that ME and MGHE were characterized in a single genetic background (Benning), due to the time and resources needed to develop the NILs. Nevertheless, QTLs M (Narvel et al. 2001; Walker et al. 2002; Walker et al. 2004) and E (Hulburt 2002; Hulburt et al. 2004) have been verified to work in different backgrounds when independently tested. From a breeding perspective, introgressing just QTL-M and QTL-E into an elite
Field cage 1

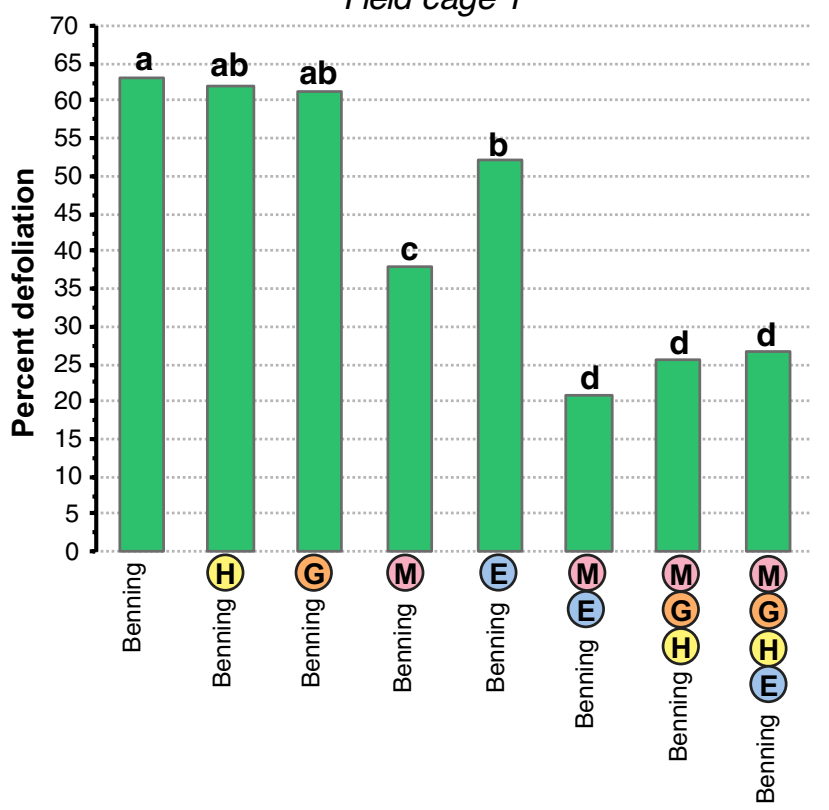

Field cage 2

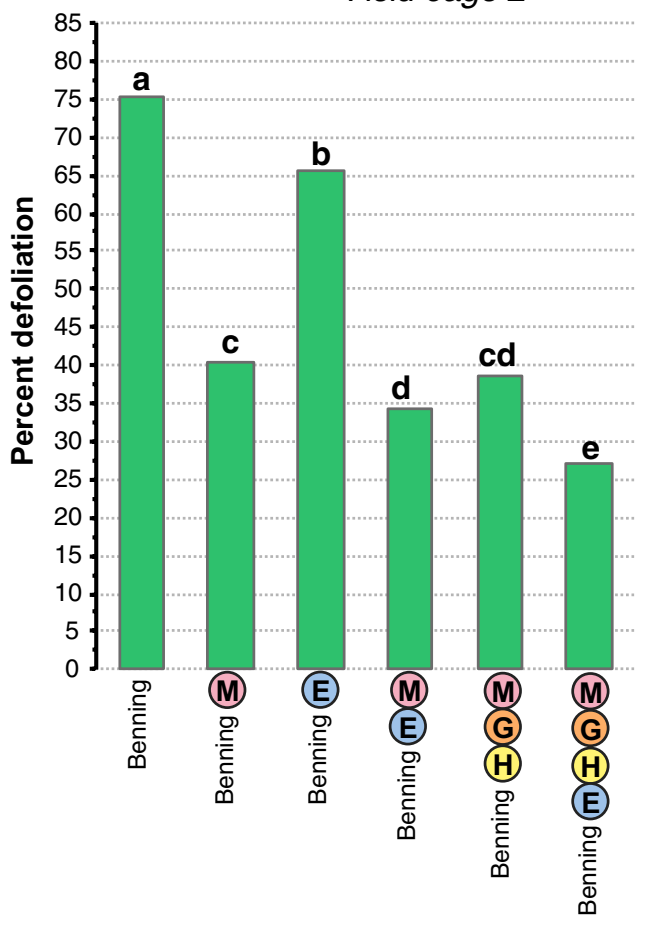

Fig. 9 Mean defoliation by SBL at 11 days after infestation, in the first and second field cage. Significant differences (Tukey-Kramer post hoc test, $p<0.05$ ) between NILs are indicated by letters

cultivar is simpler than introgressing all four QTLs. As the number of QTLs increases, pyramiding in an elite line becomes increasingly difficult; especially when selection involves several traits at a time (Bernardo 2008). Furthermore, QTL-G is associated with a yield penalty (Warrington 2006). Altogether, pyramiding the major insectresistance QTLs from PI 229358 and PI 227687 presents 


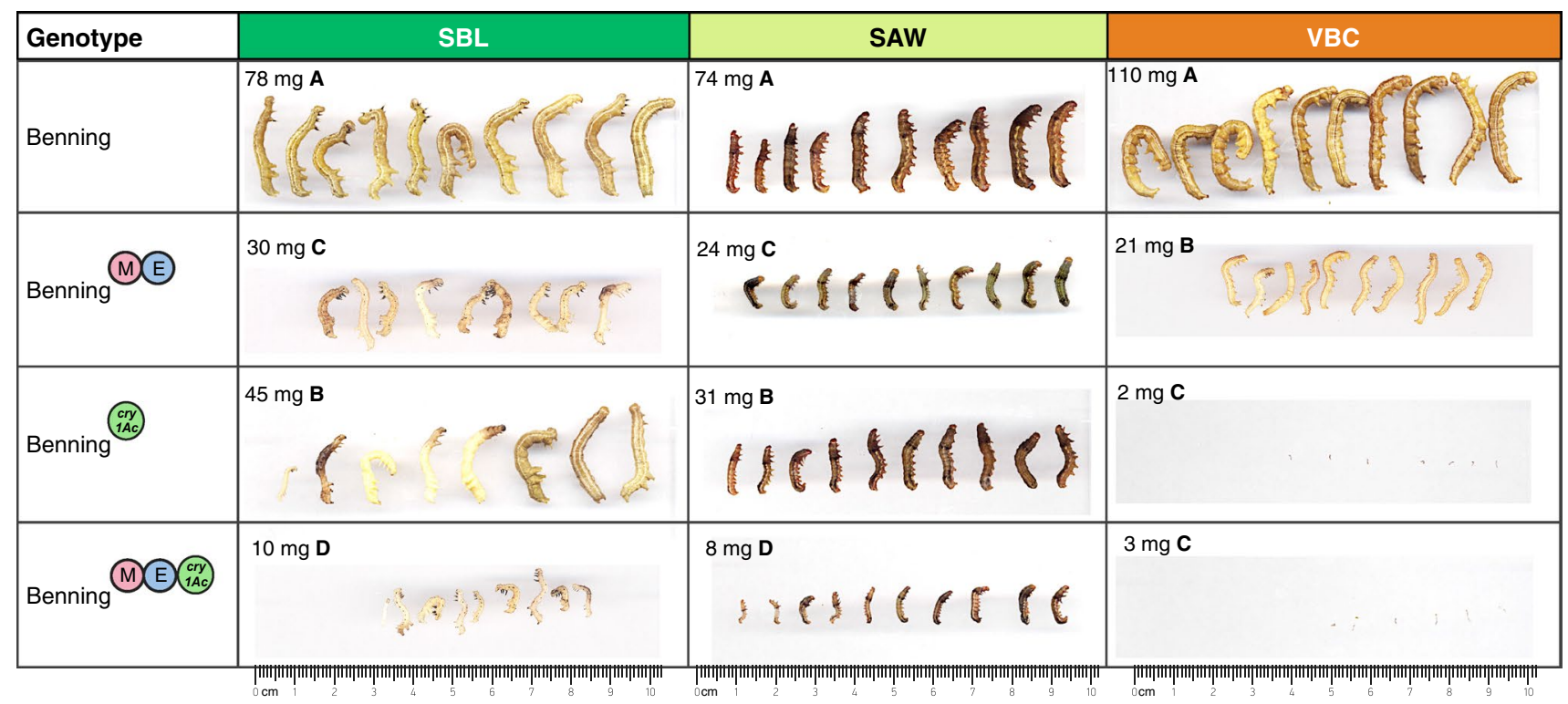

Fig. 10 Mean weight of SBL, SAW, and VBC caterpillars after feeding on insect-resistant Benning ${ }^{\mathrm{ME}+C r y l A c}$ during detached-leaf (antibiosis) assays. Significant differences (Tukey-Kramer post hoc test, $p<0.05$ ) between NILs are indicated by letters

an effective genetic combination to deploy host-plant resistance to insects in soybean.

In Brazil, the genetically modified MON $87701 \times$ MON 89788 soybean, which expresses the Bt toxin Cry1Ac, is used for the integrated pest management of lepidopteran pests (Berman et al. 2011). This soybean is resistant to SBL, VBC (Bernardi et al. 2012), tobacco budworm [Heliothis virescens (Fabricius)] (Bernardi et al. 2014a), and the recently imported old world cotton bollworm [Helicoverpa armigera (Hübner)] (Azambuja et al. 2015). However, Cry1Ac is not sufficient to protect soybeans from FAW, SAW, and the velvet armyworm [Spodoptera latifascia (Walker)] (Bernardi et al. 2014b). Frequent SAW outbreaks have been already reported in Brazil (Bueno et al. 2007; Santos 2005); SAW's high defoliation capacity (Bueno et al. 2011) and its large populations make this species an important pest that can cause severe economic losses to Brazilian soybean production. A synergistic relationship between crylAc and the insect-resistance QTLs from PI 229358 was previously reported (Walker et al. 2002; Zhu et al. 2008). PI 227687 has shown resistance to SAW via antibiosis (Souza et al. 2014). There was interest in determining if the combination of QTL-M, QTL-E and $c r y l A c$ would also provide enhanced resistance to lines with only the crylAc transgene or the QTLs by themselves. Benning ${ }^{\mathrm{ME}+c r y l A c}$ was developed and characterized in antibiosis assays. This line is more resistant than Benning $^{\mathrm{ME}}$ and Benning ${ }^{\text {crylAc}}$ against SBL and SAW. Although this combination would need to be thoroughly studied in antixenosis field-cage assays and, if possible, in field tests with natural pest infestations, the results from the antibiosis assays indicate the potential of combining QTL-M, QTL-E and $\operatorname{crylAc}$ to improve soybean resistance to insects that are naturally tolerant to crylAc. The use of this pyramid as part of a resistance management strategy (Bates et al. 2005) could help preserve the effectiveness of $\mathrm{Bt}$, which could lead to durable resistance to leaf-chewing insects in soybean.

Breeding high-yielding soybean cultivars with agriculturally relevant levels of insect-resistance has been a long-term goal. In the past, lines carrying only PI 229358 QTLs were either lower yielding (e.g., Benning ${ }^{\mathrm{MGH}}$; Warrington et al. 2008), or not highly resistant in the field (e.g., Benning ${ }^{\mathrm{MH}}$; Zhu et al. 2008). With only two insectresistance QTLs, Benning ${ }^{\mathrm{ME}}$ is at least as resistant to several important lepidopteran pests as Benning ${ }^{\mathrm{MGH}}$, without carrying QTL-G. Lines carrying QTLs from PI 229358 QTLs enhance the resistance provided by crylAc in lines like Benning ${ }^{\mathrm{MH}+\text { crylAc }}$ (Zhu et al. 2008). The combination of $\mathrm{ME}+$ crylAc described here could present an opportunity to effectively deploy Bt, in a pyramid with host-plant resistance genes.

Author contribution statement MO designed and performed the experiments, collected and analyzed data, and drafted the manuscript. JA and RB conceived the study. WP conceived the study and drafted the manuscript.

Acknowledgments This research is supported by the United Soybean Board, the USDA Grant GEO-2011-04373, and by State and Federal monies allocated to the Georgia Agricultural Experiment Stations. Special thanks to Adam Bray, David Dyck, Noah Lawler, Dean Kemp, Kurk Lance, and Dale Wood for assistance either in the 
laboratory, greenhouse or the field; and to Chad Finkenbinder for timely providing the insect eggs used in the bioassays.

\section{Compliance with ethical standards}

Conflict of interest The authors declare that they have no conflict of interest.

Open Access This article is distributed under the terms of the Creative Commons Attribution 4.0 International License (http://creativecommons.org/licenses/by/4.0/), which permits unrestricted use, distribution, and reproduction in any medium, provided you give appropriate credit to the original author(s) and the source, provide a link to the Creative Commons license, and indicate if changes were made.

\section{References}

Azambuja R, Degrande PE, Santos RO, Souza EP, Gomes CE (2015) Effect of Bt soybean on larvae of Helicoverpa armigera (Hübner) (Lepidoptera: Noctuidae). J Agr Sci 7:90-94

Bates SL, Zhao JZ, Roush RT, Shelton AM (2005) Insect resistance management in GM crops: past, present and future. Nat Biotechnol 23:57-62

Berman KH, Harrigan GG, Nemeth MA, Oliveira WS, Berger GU, Tagliaferro FS (2011) Compositional equivalence of insectprotected glyphosate-tolerant soybean MON $87701 \times$ MON 89788 to conventional soybean extends across different world regions and multiple growing seasons. J Agr Food Chem 59:11643-11651

Bernardi O, Malvestiti GS, Dourado PM, Oliveira WS, Martinelli S, Berger GU, Head GP, Omoto C (2012) Assessment of the high-dose concept and level of control provided by MON $87701 \times$ MON 89788 soybean against Anticarsia gemmatalis and Pseudoplusia includens (Lepidoptera: Noctuidae) in Brazil. Pest Manag Sci 68:1083-1091

Bernardi O, Dourado PM, Carvalho RA, Martinelli S, Berger GU, Head GP, Omoto C (2014a) High levels of biological activity of Cry1Ac protein expressed on MON $87701 \times$ MON 89788 soybean against Heliothis virescens (Lepidoptera:Noctuidae). Pest Manag Sci 70:588-594

Bernardi O, Sorgatto RJ, Barbosa AD, Domingues FA, Dourado PM, Carvalho RA, Martinelli S, Head GP, Omoto C (2014b) Low susceptibility of Spodoptera cosmioides, Spodoptera eridania and Spodoptera frugiperda (Lepidoptera: Noctuidae) to genetically-modified soybean expressing Cry1Ac protein. Crop Prot 58:33-40

Bernardo R (2008) Molecular markers and selection for complex traits in plants: learning from the last 20 years. Crop Sci 48:1649

Boerma HR, Hussey RS, Phillips DW, Wood ED, Rowan GB, Finnerty SL (1997) Registration of 'Benning' soybean. Crop Sci 37:1982

Boethel DJ (1999) Assessment of soybean germplasm for multiple insect resistance. In: Quisenbury SS, Clement SL (eds) Global plant genetic resources for insect-resistant crops. CRC Press, Boca Raton, pp 101-129

Boethel DJ (2004) Integrated management of soybean insects. In: Boerma HR, Specht JE (eds) Soybeans: improvement, production, and uses. American Society of Agronomy, Crop Science Society of America, and Soil Science Society of America, WI, pp 853-881

Bonnett OT, Bever WM (1947) Head-hill method of planting head selections of small grains. Agron J 39:442-445
Bueno RC, Parra JR, Bueno AF, Moscardi F, Di Oliveira JR, Camillo MF (2007) Sem barreira. Rev Cultiv 55:12-15

Bueno RC, Bueno AdF, Moscardi F, Parra JRP, Hoffmann-Campo CB (2011) Lepidopteran larva consumption of soybean foliage: basis for developing multiple-species economic thresholds for pest management decisions. Pest Manag Sci 67:170-174

Clark WJ, Harris FA, Maxwell FG, Hartwig EE (1972) Resistance of certain soybean cultivars to bean leaf beetle, striped blister beetle, and bollworm. J Econ Entomol 65:1669-1672

FAOSTAT (2015) FAOSTAT Database. Food and agriculture organization, Rome, Italy. http://www.faostat.fao.org. Accessed 4 Jan 2015

Fehr WR, Caviness CE (1977) Stage of development descriptions for soybeans, Glycine max (L.) Merril. Crop Sci 11:929-931

Gary DJ, Lambert L, Ouzts JD (1985) Evaluation of soybean plant introductions for resistance to foliar feeding insects. J Miss Acad Sci 30:67-82

Grant D, Nelson RT, Cannon SB, Shoemaker RC (2010) SoyBase, the USDA-ARS soybean genetics and genomics database. Nucleic Acids Res 38:843-846

Haile FJ, Higley LG, Specht JE (1998) Soybean cultivars and insect defoliation: yield loss and economic injury levels. Agron J 90:344-352

Hatchett JH, Beland GL, Hartwig EE (1976) Leaf-feeding resistance to bollworm and tobacco budworm in three soybean plant introductions. Crop Sci 16:277

Heatherly LG (2014) Soybean insect management guide. Mississippi soybean promotion board. http://WWW.MSSOY.ORG. Accessed 2 Feb 2015

Hoffmann-Campo CB, Neto JAR, de Oliveira MCN, Oliveira LJ (2006) Detrimental effect of rutin on Anticarsia gemmatalis. Pesqui Agropecu Bras 41:1453-1459

Hollowell EA, Johnson HW (1934) Correlation between rough-hairy pubescence in soybean and freedom from injury by Empoasca fabae. Phytopathology 24:12

Hulburt DJ (2002) Identifying additional insect resistance quantitative trait loci in soybean using simple sequence repeats. M.S. thesis, University of Georgia, Athens

Hulburt DJ, Boerma HR, All JN (2004) Effect of pubescence tip on soybean resistance to lepidopteran insects. J Econ Entomol 97:621-627

Johnson HW, Hollowell EA (1935) Pubescent and glabrous characters of soybeans as related to resistance to injury by the potato leafhopper. J Agric Res 51:371-381

Jones WA, Sullivan MJ (1979) Soybean resistance to the southern green stink bug, Nezara viridula. J Econ Entomol 72:628-632

Kanno H (1996) Role of leaf pubescence in soybean resistance to the false melon beetle, Atrachya menetriesi Faldermann (Coleoptera: Chrysomelidae). Appl Entomol Zool 31:597-603

Kogan M, Ortman EF (1978) Antixenosis: a new term proposed to define Painter's nonpreference modality of resistance. Bull Entomol Soc Am 24:175-176

Komatsu K, Okuda S, Takahashi M, Matsunaga R (2004) Antibiotic effect of insect-resistant soybean on common cutworm (Spodoptera litura) and its inheritance. Breeding Sci 54:27-32

Kramer CY (1956) Extension of multiple range tests to group means with unequal numbers of replications. Biometrics 12:307-310

Kramer CY (1957) Extension of multiple range tests to group correlated adjusted means. Biometrics 13:13-18

Lambert L, Kilen TC (1984a) Influence of three soybean plant genotypes and their F1 intercrosses on the development of five insect species. J Econ Entomol 77:622-625

Lambert L, Kilen TC (1984b) Insect resistance factor in soybean PI's 229358 and 227687 demonstrated by grafting. Crop Sci 24:163

Lambert L, Tyler J (1999) Appraisal of insect-resistant soybeans. In: Webster JA, Wiseman BR (eds) Economic, environmental, and 
social benefits of insect resistance in field crops. Thomas Say, Entomological Society of America, Lanham, pp 131-148

Layton MB, Boethel DJ, Smith CM (1987) Resistance to adult bean leaf beetle and banded cucumber beetle (Coleoptera: Chrysomelidae) in soybean. J Econ Entomol 80:151-155

Li W, Van K, Zheng D-H, Liu W, Lee Y-H, Lee SY, Lee J-H, Lee S-H (2008) Identification of QTLs associated with resistance to Riptortus clavatus Thunberg (Heteroptera: Alydidae) in soybean (Glycine max L. Merr.). J Crop Sci Biotechnol 11:243-248

Luedders VD, Dickerson WA (1977) Resistance of selected soybean genotypes and segregating populations to cabbage looper feeding. Crop Sci 17:395

Musser FR, Catchot Jr AL, Davis JA, Herbert Jr DA, Lorenz GM, Reed T, Reisig DD, Stewart SD (2014) 2013 Soybean Insect Losses in the Southern US. Midsouth Entomol 7:15-28

Narvel JM, Walker DR, Rector BG, All JN, Parrott WA, Boerma HR (2001) A retrospective DNA marker assessment of the development of insect resistant soybean. Crop Sci 41:1931

Oerke EC (2005) Crop losses to pests. J Agr Res 144:31-43

Painter RH (1951) Insect resistance in crop plants. Soil Sci 72:481

Piubelli GC, Hoffmann-Campo CB, De Arruda IC, Franchini JC, Lara FM (2003) Flavonoid increase in soybean as a response to Nezara viridula injury and its effect on insect-feeding preference. J Chem Ecol 29:1223-1233

Rasband WS (1997) Image J, U.S National Institutes of Health, Bethesda, Maryland, USA, http://imagej.nih.gov/ij/, 1997-2014. Accessed 10 June 2011

Rector BG, All JN, Parrott WA, Boerma HR (1998) Identification of molecular markers linked to quantitative trait loci for soybean resistance to corn earworm. Theor Appl Genet 96:786-790

Rector BG, All JN, Parrott WA, Boerma HR (2000a) Quantitative trait loci for antibiosis resistance to corn earworm in soybean. Crop Sci 40:233-238

Rector BG, All JN, Parrott WA, Boerma HR (2000b) Quantitative trait loci for antixenosis resistance to corn earworm in soybean. Crop Sci 40:531-538

Santos KB (2005) Biologia de Spodoptera eridania (Cramer) (Lepidoptera: Noctuidae) em diferentes hospedeiros. Neotrop Entomol 34:903-910

Santos MO, Adang MJ, All JN, Boerma HR, Parrott WA (1997) Testing transgenes for insect resistance using Arabidopsis. Mol Breed 3:183-194

Shaphiro SS, Wilk MB (1965) An analysis of variance test for normality. Biometrika 52:591-611

Silva JPGF, Baldin ELL, Souza ES, Canassa VF, Lourenção AL (2013) Characterization of antibiosis to the redbanded stink bug Piezodorus guildinii (Hemiptera: Pentatomidae) in soybean entries. J Pest Sci 86:649-657

Souza BHS, Silva AG, Janini JC, Júnior ALB (2014) Antibiosis in Soybean Genotypes and the Resistance Levels to Spodoptera eridania (Cramer) (Lepidoptera: Noctuidae). Neotrop Entomol 43:582-587

Stewart CN, Adang MJ, All JN, Boerma HR, Cardineau G, Tucker D, Parrott WA (1996) Genetic transformation, recovery, and characterization of fertile soybean transgenic for a synthetic Bacillus thuringiensis crylAc gene. Plant Physiol 112:121-129
Talekar NS, Lee HR (1988) Resistance of soybean to four defoliator species in Taiwan. J Econ Entomol 81:1469-1473

Talekar NS, Lin CP (1994) Characterization of resistance to limabean pod borer (Lepidoptera: Pyralidae) in soybean. J Econ Entomol $87: 821-825$

Ting CL (1946) Genetic studies on the wild and cultivated soybeans. Agron J 38:381-393

Tukey J (1953) Multiple comparisons. J Am Stat Assoc 48:624-625

USDA-ARS (2015) Genetic Resource Information Network (GRIN). http://www.ars-grin.gov/npgs/acc/acc_queries.html. Accessed 7 Feb 2015

Van Duyn JW, Turnipseed SG, Maxwell JD (1971) Resistance in soybeans to the Mexican bean beetle. I. Sources of resistance. Crop Sci 11:572-573

Van Duyn JW, Turnipseed SG, Maxwell JD (1972) Resistance in soybeans to the Mexican bean beetle: II. Reactions of the beetle to resistant plants. Crop Sci 12:561

Walker D, Roger Boerma H, All J, Parrott W (2002) Combining crylAc with QTL alleles from PI 229358 to improve soybean resistance to lepidopteran pests. Mol Breed 9:43-51

Walker DR, Narvel JM, Boerma HR, All JN, Parrott WA (2004) A QTL that enhances and broadens Bt insect resistance in soybean. Theor Appl Genet 109:1051-1057

Warrington CV (2006) Seed yield and insect resistance of near-isogenic soybean lines with introgressed resistance QTL from PI 229358. M.S. thesis, University of Georgia, Athens, p 49

Warrington CV, Zhu S, Parrott WA, All JN, Boerma HR (2008) Seed yield of near-isogenic soybean lines with introgressed quantitative trait loci conditioning resistance to corn earworm (Lepidoptera: Noctuidae) and soybean looper (Lepidoptera: Noctuidae) from PI 229358. J Econ Entomol 101:1471-1477

Wilcox JR (2004) World distribution and trade of soybean. In: Boerma HR, Specht JE (eds) Soybeans: improvement, production, and uses American Society of Agronomy Inc. Madison, WI, pp 1-14

Ye G, Smith KF (2008) Marker-assisted gene pyramiding for inbred line development: Basic principles and practical guidelines. Int $\mathbf{J}$ Plant Breed 2:1-10

Zhu S, Walker DR, Boerma HR, All JN, Parrott WA (2006) Fine mapping of a major insect resistance QTL in soybean and its interaction with minor resistance QTLs. Crop Sci 46:1094

Zhu S, Walker DR, Warrington CV, Parrott WA, All JN, Wood ED, Boerma HR (2007) Registration of four soybean germplasm lines containing defoliating insect resistance QTLs from PI 229358 introgressed into 'Benning'. J Plant Regist 1:162

Zhu S, Walker DR, Boerma HR, All JN, Parrott WA (2008) Effects of defoliating insect resistance QTLs and a crylAc transgene in soybean near-isogenic lines. Theor Appl Genet 116:455-463

Zhu S, Saski CA, Boerma HR, Tomkins JP, All JN, Parrott WA (2009) Construction of a BAC library for a defoliating insect-resistant soybean and identification of candidate clones using a novel approach. Plant Mol Biol Rep 27:229-235 